International Journal of Language Education

Volume 5, Number 4, 2021, pp. 337-355

ISSN: $2548-8457$ (Print) 2548-8465 (Online)

Doi: https://doi.org/10.26858/ijole.v5i4.22495

\title{
Multimodal Approach in Online EFL Class Using Islamic Learning Materials: Students' Perspective
}

\author{
Dewi Suriyani Djamdjuri \\ Universitas Negeri Jakarta, Indonesia \\ Email:DewiSuriyaniDjamdjuri_9906920010@mhs.unj.ac.id \\ Muchlas Suseno \\ Universitas Negeri Jakarta, Indonesia \\ Email:muchlas-suseno@unj.ac.id \\ Shafruddin Tajuddin \\ Universitas Negeri Jakarta, Indonesia \\ Email: shafruddin.ta@unj.ac.id \\ Ninuk Lustyantie \\ Universitas Negeri Jakarta, Indonesia \\ Email:ninuk.lustyantie@unj.ac.id \\ Uwes Anis Chaeruman \\ Universitas Negeri Jakarta, Indonesia \\ Email:uwes@unj.ac.id
}

Received: 22 July 2021

Reviewed: 1 August 2021-30 October 2021

Accepted: 5 December 2021

\begin{abstract}
This study aims to find out how students' perspectives on learning English use 21st century learning strategies through a multimodal approach to teaching English for EFL students. A lecture was conducted online for one semester (four months) by using Islamic topics as learning materials. The learning materials were presented and discussed, then students were asked to write or talk about the topics. This study uses a descriptive qualitative approach to data collection through the provision of questionnaires and interviews with 47 students of the Islamic Broadcasting Program at the Faculty of Islamic Religion at a private Islamic university in Bogor, Indonesia, in the English language course. From the data collected through a set of questionnaires and interviews it can be concluded that, 1) the majority of respondents are interested in using Islamic materials to learn English; 2) the majority of respondents state that Islamic materials assisted them in improving their English language skills; 3) The majority of respondents are interested in using online Islamic resources using multimodal approach. Furthermore, the respondents stated that the multimodal approach to learning is very interesting, effective, and can help them to learn English. In addition, students wished that direct interaction between lecturers and students could continue to function well. Hence, the
\end{abstract}


use of multimodal-based Islamic materials could provide interactive opportunities between lecturers and students.

Keywords: 21st century learning; multimodal approach; English learning; Islamic material

\section{Introduction}

The 21 st century educational paradigm has experienced a shift marked by differences in learning orientation (Karami, 2019; Muhali, 2019). Learning in the previous century emphasized literacy in reading, writing, and mathematics, which in the twenty-first century is used as the foundation for developing new literacies, namely human, data, and technology literacy, which are critical in dealing with the current and future globalization era (Tan et al., 2020). Innovative learning in the 21 st century is activity-oriented towards training of essential skills according to the 21 st century skills framework, namely life and career skills, innovation and learning skills, and information, media, and ICT skills (Sakulprasertsri, 2020). Moreover, the development of the 21st century world is marked by the use of information and communication technology in all aspects of life, including in the learning process (Baroya, 2018). This is marked by the use of information and communication technology in all aspects of life, including in the learning process.

Along with the rapid development of technology, technological advances have created great expectations among many teachers, administrators, researchers, and policy makers, who believe that digital devices offer great promise as learning tools (Khotimah \& Wahyu, 2020). Understanding literacy or literateness is important, not only for understanding texts, but for broader learning, success in education, and work. It is even important for our social life, because of email, text, and social networking sites (Khusniyah \& Lustyantie, 2017). The emergence of the first digital media in the form of digital books in Indonesia in 1998 continued to move book writers and other publishers to create and sell their works in digital versions (Khotimah \& Wahyu, 2020). With the rapid development of advances in digital technology, it is dramatically changing all the learning tools available to teachers and students. This technological advancement has created excitement among many people because of its potential to be used as an instructional tool for literacy or literacy education.

Researchers find multimodal-based media to be very attractive because they not only simulate the experience of reading or listening to stories, but also provide technological improvements that make the reading, viewing and listening experience qualitatively different from just a traditional paper book. Electronic media usually contains a combination of features, such as animated images and background sounds and music that dramatize the text (Bus et al., 2015; Sakulprasertsri, 2020). Digital media is an activity of combining narrative stories with digital content in which there are images, sound, music, and videos so that they can produce an interesting short film that can be made in an instructional format for teaching, persuasive, historical, or as a reflection activity (Yi et al., 2019). From the statement above, it can be concluded that multimodalbased digital media books are widely used because they have several advantages, namely easy access and can support the teaching and learning process (Irawati, 2018). Many education experts believe that digital media can be applied to several subjects, and can accommodate a variety of student learning styles (Moody, 2010; Wu, 2020). Furthermore, Moody said that digital media has a variety of features that are equipped with sophisticated technology (Moody, 2010). In addition, previous research reported that the utility of multimodal approach in the English learning is essential. However, it is obvious that almost none of them involves the Islamic religious material in the teaching learning processes. Therefore, this research was conducted to know how are the 
students' perspectives when the lecturer provided Islamic materials to blend with the material of English language for online English learning using multimodal approach.

Promoting religious education in the teaching and learning process is crucial as it is believed to be able to instil noble values or good character in students' lives (Anshari \& Widyantoro, 2020; Cahyo et al., 2019; Djamdjuri, 2020). In addition, combining religious values with language learning may equip students with good skills as well as commendable morals. By so doing, it is expected that Muslim students will find it easier to understand the English lesson. For this purpose, the learning design must be adapted to comply with the needs of students (Dewanti \& Iskandar, 2012; Purnawati \& Iskandar, 2019). Based on this, this research was focused on the students' perspectives of the use of Islamic materials in the English learning delivered online using a multimodal approach.

\section{The multimodal perspective on language and literature learning}

The world of work also demands changes in competence. The ability to think critically, solve problems, and collaborate are important competencies in entering the life of the 21 st century (Halimah et al., 2020; Muhali, 2019). Schools are required to be able to prepare students to enter the 21st century. The subjects of the 21st century consist of English (the official language of each country), the world's lingua franca, art, mathematics, economics, natural science (science), geography, history, government, and citizenship, while the theme of the 21st century includes global awareness; financial, economic, business and entrepreneurial literacy; awareness as a citizen; health literacy; and environmental literacy (Karami, 2019). The characteristics of learning to practice these essential skills lead to an interactive, holistic, integrative, scientific, contextual, thematic, effective, collaborative, and student-centred learning process, so that educators can design activities in practice by selecting learning method models that can accommodate the characteristics as a whole comprehensively (Muhali, 2019; Unsworth \& Mills, 2020) . Assessment in 21st century learning is structured and developed to measure student learning achievement, which includes knowledge competence (critical thinking and problem solving, creativity and innovation, collaboration, communication), intrapersonal competence (team work skills, collaboration, communication, cooperation, and coordination), and interpersonal competence (the ability to work with others, such as self-management skills, cooperation, effective communication, and the ability to maintain emotional relationships with others) (Tan et al., 2020; Unsworth \& Mills, 2020). Thus, innovative learning in the 21 st century creates human resources who are literate with information, data and technology needed to face competition in life and the labour market in the current and future globalization era.

Multimodal learning refers to an embodied learning situation involving multiple sensory systems and learner action systems (Lustyantie \& Arung, 2020; Massaro, 2012). This type of learning has traditionally been emphasized by students with learning challenges, and can include a variety of visual inputs in addition to text. Images, art, films, videos, and graphic organizers are some examples. Auditory input can include text-to-speech synthesizers, various forms of singing and musical instruments, rhymes, and spoken language games (Massaro, 2012). In particular, multimodal is closely related to language, which is a perspective to approach meaningful communication interaction both verbally and nonverbally (Lustyantie \& Arung, 2020). Furthermore, (Lustyantie \& Arung, 2020) mentioned that a meaningful interaction can be produced from a simple form of symbol, sign, or symbol, which is usually called a tent system or information channel (mode) that is visual, audio, or audio-visual. When it comes to learning, there is no "one size fits all". That is, we don't know a strategy that fits everyone. Although this statement 
seems plausible, the everyday realities of student life in schools are often in sharp contrast to this basic teaching. Schools often apply only one strategy that applies to all students. Learning becomes monotonous and students find it difficult to develop. Expert teachers will make use of multiple modes, rather than blindly following one approach, as this is a way of ensuring that all learners experience success as learners (Narey, 2017). There are ways to avoid the rigid set of polarizations and find places where teachers can deftly navigate learners' needs while also relying on complex research. Clearly, it is possible to respect students' ways of knowing while meeting academic standards. It is obvious that modern education today combines theory, research, and practice (Narey, 2017). Multimodal experiences, particularly those focused on developing the learner's capacity to produce and interpret visual texts, are essential for twenty-first century learning. Visually rich digital and media-based texts stand out in educational discourse about preparing learners for the global future of the twenty-first century (Victor, 2016). In discussions of learning, many early literacy professions also express familiarity with the term multimodality, although not necessarily a substantive understanding of its application in practice.

Throughout history, humans have used visual, auditory, kinesthetics, and sensory modalities to generate and consume various forms of text. From ancient storytelling traditions to modern web pages on the Internet, people have tried to make meaning through images, sounds, gestures, and touch (Eisenmann \& Summer, 2020; Narey, 2017; Wu, 2020). Cultural beliefs and values influence textual production and consumption because needs and goals are assigned to resources, technology, and access. Over time, cultural shifts inevitably trigger changes in textual forms and functional modalities for creating meaning. Recently, advances in digital technology and widespread media using trigonometry have experienced a recent cultural shift where graphic sources (e.g., photos, videos, graphics) serve as the primary form of communication (Lustyantie \& Arung, 2020; Narey, 2017). From the explanation above, it can be concluded that 21st century learning has developed rapidly. The use of a technology-based and internet-based multimodal approach is one of the most effective learning methods. According to (Zubaidah, 2019), life in the 21 st century demands various skills that must be mastered by a person, so it is expected that education can prepare students to master these skills in order to become successful individuals in life (Abu-Ayfah, 2019). Important skills in the 21st century are still relevant to the four pillars of life, which include learning to know, learning to do, learning to be and learning to live together. Each of these four principles contains specific skills that need to be empowered in learning activities, such as critical thinking skills, problem solving, metacognition, communication skills, collaboration, innovation and creation, information literacy, and various other skills.

\section{Online English learning}

Technology continues to play a significant role in today's English language classrooms in order to promote language development (Hussein \& Barzani, 2021). The use of technology in current curricula was limited, but it was dominated by the use of Technology Literacy, which was prominently included in the components of Assessments, Learning Media, and/or Learning Methods (Purnawati \& Iskandar, 2019). Though E-learning, with its various terms, has emerged since 2002, it is the art and science of integrating a variety of relevant learning materials and activities into which students can collaborate and brainstorm (Chaeruman et al., 2020). E-learning is a pedagogical technology that encourages students to study in more individualized, active, and cooperative ways. Knowledge is no longer passed down from authority but rather constructed in an open, changing, and dialogic environment, allowing for the growth of communal intelligence (Fandiño \& Velandia, 2020). Through the use of media and technology tools, as well as a sustained 
and dialogic conversation, e-learning focuses on developing and maintaining people's networks in their personal contexts.

The integration of social media as an auxiliary tool for EFL learners to study language effectively has been investigated quite a lot in many countries(Irawan et al., 2020; Khan et al., 2021; Wang \& Chen, 2020). It is predicted that the growth of social media in the form of instructional such as YouTube and Telegram will be able to supply solutions. YouTube, in addition to being a source of entertainment and news, may also be used to study (Irawan et al., 2020; Wang $\&$ Chen, 2020). Learning English on YouTube was thought to be more flexible, entertaining, and participatory than formal classroom learning. However, students who wished to improve their English or prepare for English examinations found this casual learning technique to be less effective (Wang \& Chen, 2020). Other media is Telegram. According to (Abu-Ayfah, 2019; Alakrash et al., 2020; Lestari \& Wardhono, 2020) the majority of EFL students in higher education viewed Telegram as a valuable tool for English language study, particularly vocabulary building. In addition, the integration of Telegram Bot API into EFL students' learning progressed significantly, and the majority of them were satisfied with this media use (Lestari \& Wardhono, 2020). Moreover, through quassy-experimental design, it has been proved that the telegram is an effective teaching tool that stimulates students to acquire vocabulary in a fun way. According to the results of the experimental post-test, the report concludes with implications and recommendations (Alakrash et al., 2020). Those e-learning media are multimodal media comprising text-to-speech synthesizers, various forms of singing and musical instruments, rhymes, and spoken language games, and include all visuals, art, films, videos, and graphic organizers.

\section{Islamic teaching materials}

Due to its prominence as a worldwide language for communication, whether in commerce or academic, English has been the most popular language to study as a foreign/second language for generations (Rehman \& Perveen, 2021). The Ministry of National Education of Indonesia states that language has a critical role in students' intellectual, social, and emotional development, as well as being a key component of academic achievement in all subjects (Apriani et al., 2019). Language learning is supposed to assist students get to know themselves, their culture, and the cultures of others, express themselves in the language, and discover and utilise their analytical and imaginative abilities. Learning English is required to make students able to communicate with politeness and courtesy both verbally and in writing for various purposes (e.g., in building social ties, enhancing knowledge through data exchange) (Pohan \& Malik, 2018). The foundation of interaction that must be upheld is the civility principles that apply in a civilized culture. They also include tolerance, respect for the other person, the ability to collaborate, confidence, diligence, creativity, tenacity, and the ability to adapt to kindness and honesty (Pike et al., 2020).

Teaching materials, according to the Indonesian Ministry of National Education (2011: 2), are all forms of materials used to assist teachers in carrying out the educational process (Apriani et al., 2019; Ratih \& Taufina, 2019). The materials are also a collection of materials that are arranged systematically so as to create an environment or atmosphere that allows students to learn. Those consist of printed materials and interactive teaching materials (Sarip et al., 2018). The teaching materials used in the educational process will determine the achievement of each of the basic competencies proclaimed. Likewise, teaching materials can be an effective means of instilling character or moral values (Boeriswati, 2013). Teaching materials that meet good criteria can give birth to an efficient educational process (Ratih \& Taufina, 2019). On the other hand, if the teaching materials do not match the criteria, there will be various cases in education. However, 
the teaching materials used should not only help the educational process but also look at the overall achievement of the basic competencies to be achieved as stated in the 2013 Curriculum. Indeed, a number of schools have begun to emerge that integrate values into religious and general science (Djamdjuri \& Wulandari, 2018; Rohmah, 2012). As many scholars believe that if someone is desperate to learn English as a second language, he must be open to the language and comfortable using it in everyday situations, as all native speakers do (Assiddiq, 2019; Rehman \& Perveen, 2021; Umirova, 2020).

The use of Islamic materials in learning is intended to balance the current flow of communication and information (Cahyo et al., 2019; Darmayenti et al., 2021). With the massive internet media, it opens up opportunities for students to be able to access various information without filters. For this reason, in addition to having expertise according to 21 st century competencies, students need to be equipped with Islamic characters and an understanding of good religious principles (Rohmah, 2012; Sih, 2020). To obtain good character values, it is necessary to select teaching materials that are in accordance with the identity background of the students (Pohan \& Malik, 2018). Especially if it is associated with the identity of the majority of Indonesians as Muslims (Kendiani, 2020). Religious teachings are believed to be the main reference for inculcating character values that are in accordance with the identity of a nation that believes in the one and only God (Suprayitno et al., 2019; Ummah, 2019). Islamic values can be integrated into language teaching through the use of teaching materials (Djamdjuri, 2020; Sarip et al., 2018). As such, those teaching materials can also contain cultural values and affect students' lives (Lekawael et al., 2018).

In terms of improving students' English skills, researchers used a multimodal approach through utilizing Islamic teaching materials in the form of online videos by English native speakers from Youtube that discuss Islamic themes. From this material, it would develop into class discussions and questions and answers that would involve English language skills in terms of listening, reading, speaking and writing. In addition, students were also asked to present and provide comments and conclusions on the materials they were studying. Integrating Islamic values into teaching English could lead students to have a better attitude towards English (Rohmah, 2012). Several previous studies have mentioned the effectiveness of Islamic teaching materials in learning English (Anshari \& Widyantoro, 2020). Islamic materials which are integrated into English learning can attract students' interest (Djamdjuri, 2020; Gusmuliana et al., 2020). As well the use of Islamic film or movie can increase students' motivation in learning English (Djamdjuri \& Wulandari, 2018). It can increase students' learning motivation in addition to improving their interest in learning.

\section{Research methodology}

This study was conducted using a descriptive qualitative approach (Creswell \& Creswell, 2018; Huges, 2003; Mills \& Gay, 2018). Regarding this, a survey, followed by an open-ended interview was made at the Islamic Broadcasting program, Faculty of Islamic Religion, at one of the Islamic Universities in Bogor, Indonesia, in the academic year 2020/2021. For this purpose, a holistic approach was applied to investigate how students perceive the incorporation of Islamic materials in the English learning delivered online. The data derived from 47 students (21 male and 26 females) were analyzed to provide conclusions based on the results of questionnaires and student interviews.

The interview was made after administering the questionnaires to verify the students' responses. For this purpose, the interviewees were selected in line with the types of questions and 
five out of forty- seven responses were randomly chosen to represent the whole respondents. In this regard, three open-ended interview questions were raised to find out the students' perspectives on the use of Islamic English materials delivered through multimodal approach in the teaching of English.

The derived data were analyzed using systematic analysis procedures (Gall et al., 2007). This form of analysis starts with reading and comprehending the entire data set, coding the entire data set, storing the coded data in the matrix, and selecting key categories among sub-themes. The data from questionnaires are presented using charts and descriptions, while the interview findings are presented using R1 (participant number 1), R2 (participant number 2), and R3 in that sequence. The result report is divided into 2 columns: participants on the left and their extracts on the right.

\section{Finding and discussion}

Finding

As noted, the data were derived from the questionnaires and verified through interviews on learning English using Islamic materials. There were 47 students majoring in the Islamic Broadcasting Program in the Faculty of Islamic Religion Semester 2 in the academic year 2020/2021 who took English classes delivered online. Online or distance learning was conducted due to the pandemic condition in this era. Based on the data obtained, the authors analysed the results of this study into two main parts: 1) the results of a questionnaire regarding students' perspective on the learning of English using Islamic materials and 2) the results of interviews revealing students' perspective on the application of multimodal approach.

\section{Learning English using Islamic materials}

From the results of data collection, the following data was obtained from the questionnaire. Question number 1: Are you interested in using Islamic materials in learning English?

The data from Figure 1 shows a total of 47 responses. It can be broken down into the following categories based on the 47 respondents who responded: A total of 28 people or $59.6 \%$ of respondents expressed that they were interested in. There were 14 respondents or $29.8 \%$ stated that they were very interested in. Then there were 5 respondents or $10.6 \%$ stated less interested in. From this data, the researchers concluded that most of the respondents or $59.6 \%$ were interested in. Moreover, there were 14 respondents or $29.6 \%$ were very interested in using Islamic materials in learning English. From the calculation of the data, it can be concluded that most of the respondents or $89.4 \%$ were attracted to using Islamic materials. It can be apparent from the following Figure 1: 


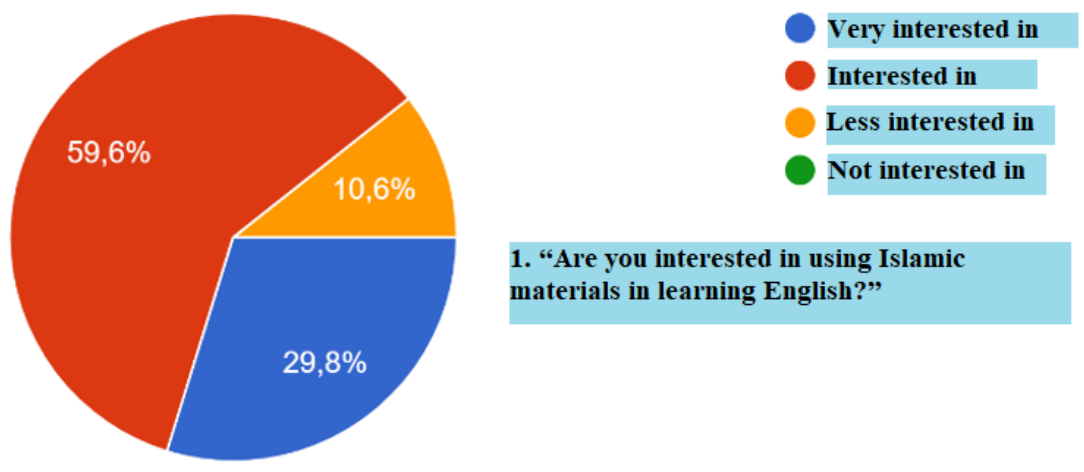

Figure 1. Students' interest in using Islamic material in learning English

Question number 2: Do Islamic materials help you improve your English skills?

The following Figure 2 shows the 47 respondents who gave responses. It can be broken down into the following categories: There were 9 respondents or $19.1 \%$ stated that Islamic material was very helpful for them. A total of 30 people or $63.8 \%$ of respondents stated that Islamic materials helped them. Then there were 8 respondents or $17 \%$ stated that those were not really helpful. From this data, the researchers concluded that most of the respondents or $82.9 \%$ stated that Islamic materials facilitated them in improving their English language skills, as it can be perceived from the following Figure 2:
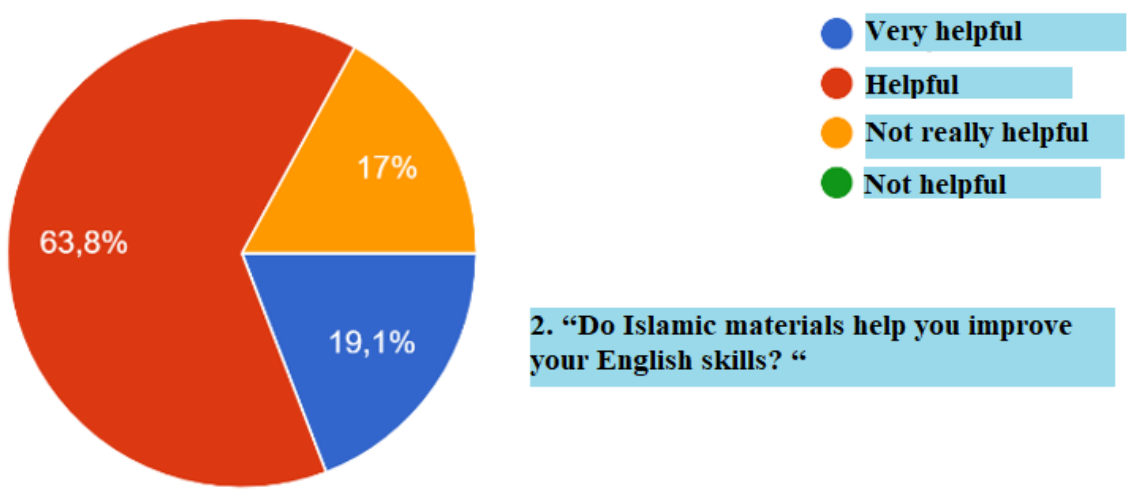

\section{2. "Do Islamic materials help you improve your English skills? “}

Figure 2. Islamic materials improve English language skills

Question number 8: Are you interested in the Islamic material created by your lecturer through multimodal approach (a combination of text, images, sound, video and web)?

The following Figure 3 question number 8 shows from the 47 respondents who gave responses, it can be broken down into following categories: There were 10 respondents or $21.8 \%$ stated that Islamic material created using multimodal digital approach is very interesting for them. A total of 33 people or $70.2 \%$ of respondents stated that they were interested in. Then there were 4 respondents or $17 \%$ stated that they were not interested in. From this data, the researchers 
concluded that most of the respondents or $91.5 \%$ stated that Islamic materials created using multimodal approach are fascinating, as it can be perceived from Figure 3:
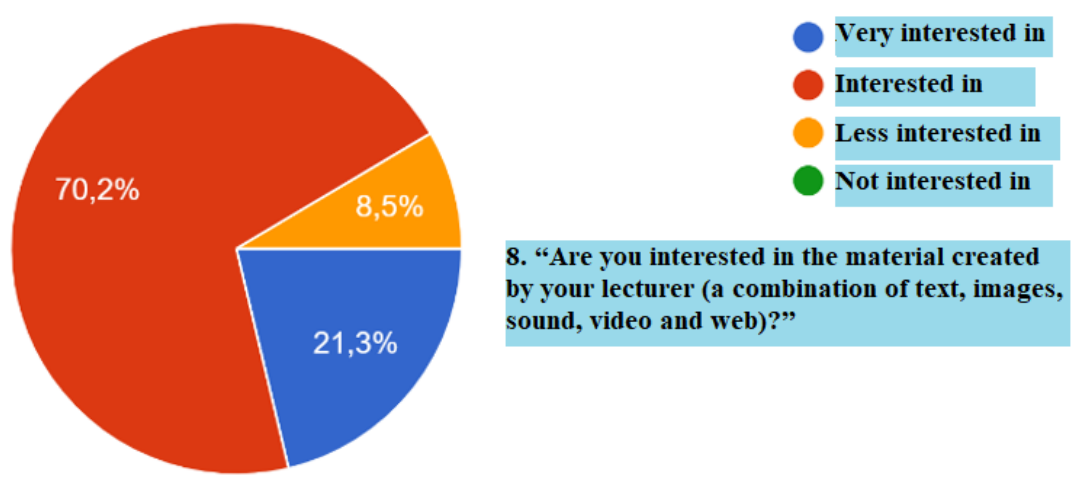

Figure 3. Students' interest in Islamic material created using multimodal digital approach

Question number 9: Are you happy with the choice of words, pictures, videos, sounds and the web made by the lecturer?

The following Figure 4 shows from the 47 respondents who gave responses, it can be broken down into following categories: There were 38 respondents or $80.9 \%$ stated they are happy with the choice of words, pictures, videos, sounds and the web made by the lecturer. A total of 7 people or $14.9 \%$ of respondents stated that they are happy. Then there were 2 respondents or $4.3 \%$ stated that they were not really happy. From this data, the researchers concluded that most of the respondents or $95.8 \%$ stated that learning materials created using multimodal approach made students joyful and pleasure. The following Figure 4 shows the detail.
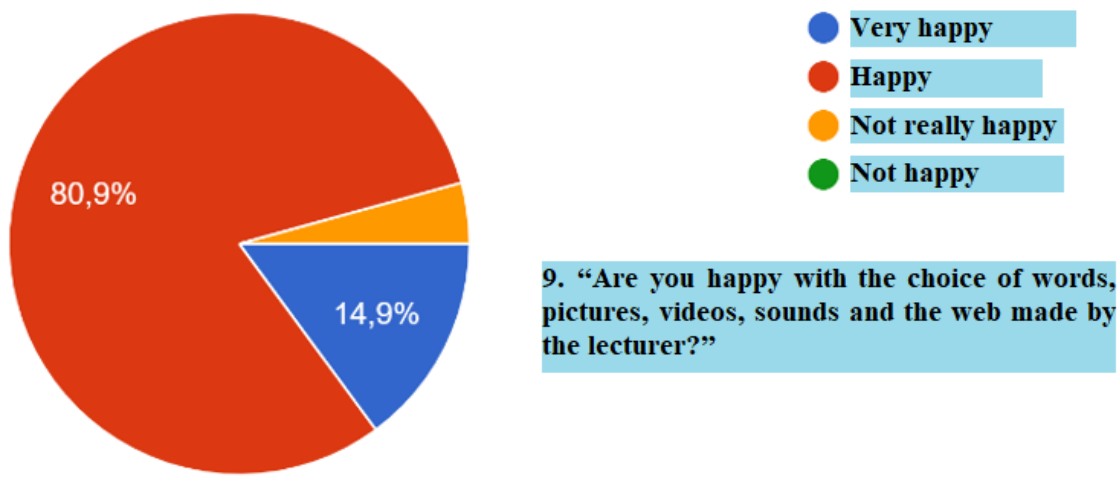

Figure 4. Students' interest in materials chosen and presented using multimodal digital book

Furthermore, from the results of the interviews, the data was analyzed to represent the respondents as a whole. The answers were also classified according to the type of questions. To find out the respondent's perspective on the use of Islamic English material, the researchers gave three interview questions that were open-ended questions. From the 47 respondents who gave a response, the researchers randomly chose the answers from 5 respondents to be analyzed. The 
following are the findings and discussion:

Question 1: What do you think about learning English using Islamic materials? Respondents gave their answers as follows:

Participants Extracts

R7 Add insight in language

R16 Alhamdulillah, happy

R23 In my opinion, learning English with an Islamic theme will not only gain knowledge in English, but we will also gain knowledge about Islam at the same time. So we get double knowledge in this lesson

R31 Help us in explaining our understanding of Islam, using English. this is in accordance with the purpose of this study program, namely da'wah

R44 Very insightful

Question 2: What do you think about learning Islamic English through multimodal-based online media? The respondents' answers are as follows:

\author{
Participants Extracts \\ R7 It is very interesting and innovative in learning \\ R16 Interested, God willing, easy to understand \\ R23 I think it really sharpens creativity, thank you for the learning method in this semester \\ R31 Indispensable, but must be reactionable (directly interactive). So, like two-way \\ communication \\ R44 Effective for improving learning
}

After presenting the data from the set of questionnaire and interview dealing with the use of Islamic materials in English teaching, the next section presents the data about learning English through multimodal approach.

\title{
Learning English through multimodal approach
}

Concerning with learning English through multimodal approach, the data were gained from questions number 3, 4, 5, 6 and 7, such as presented in the following descriptions and charts. Question number 3: Are you interested in learning English online?

The next Figure 5 shows a total of 47 participants who gave responses. It can be detailed as follows: A total of 25 or $53.2 \%$ of respondents expressed interest in. There were 3 respondents or $6.4 \%$ stated that they were very interested in. Then there were 18 respondents or $17 \%$ stated that they were not interested in. Then, 18 respondents or $38.3 \%$ and 1 respondent or $2.1 \%$ stated they were not really interested. From this data, the researchers concluded that most of the respondents or $60 \%$ were interested in using online Islamic materials in learning English, while $40 \%$ felt that they prefer to learn face-to-face in the classroom. To make it clear, let us see Figure 5 below: 


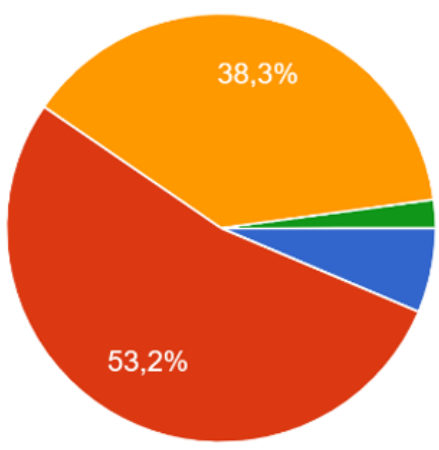

Very interested in

Interested in

Less interested in

Not interested in

3. "Are you interested in learning

English online?"

Figure 5. Learning English online

Question number 4: What learning media do you use most often for learning English online?

Figure 6 shows a total of 47 responses who gave responses. It can be detailed as the following categories: There were 28 respondents or $59.6 \%$ chose YouTube. A total of 9 people or $19.1 \%$ of respondents chose Film/Movie. Then there were 5 respondents or $10.6 \%$ chose audio, radio or music. 5 respondents or $10.6 \%$ chose communication. For more details, see the following Figure 6.
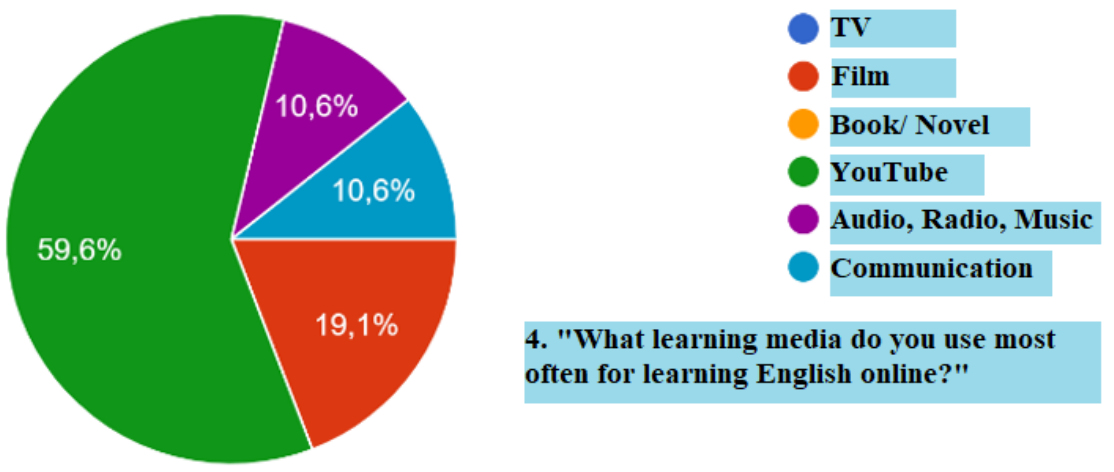

4. "What learning media do you use most often for learning English online?"

Figure 6. The most frequently used learning media in learning English

Question number 5: What communication media do you often use in learning?

A total of 47 responses are shown in Figure 7. Zoom was chosen by 24 people, or $51.1 \%$ of total respondents. The Telegram was chosen by 23 respondents, or $48.9 \%$ of those who responded. See the figure 7 below for further information. 

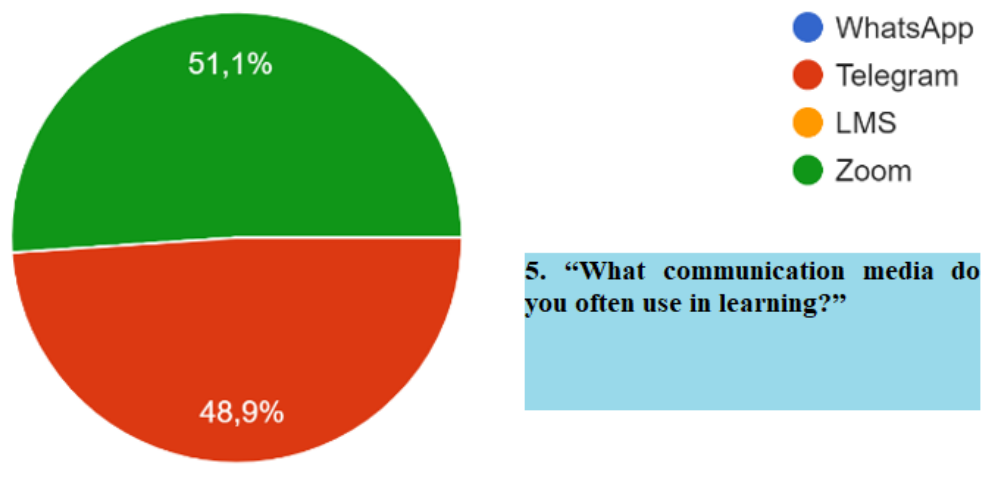

Figure 7. The most frequently used communication media in learning

Question number 6: Are you happy with the choice of words, pictures, videos, sounds and the web made by the lecturer?

Figure 8 shows a total of 47 responses who gave responses. It can be detailed into the following categories: There were 32 respondents or $68.1 \%$ felt happy. A total of 6 people or $12.8 \%$ of respondents selected to feel very happy. Then there were 7 respondents or $14.9 \%$ felt not really happy. 2 respondents or $4.3 \%$ chose stated unhappy. For more details, see the following Figure 8.

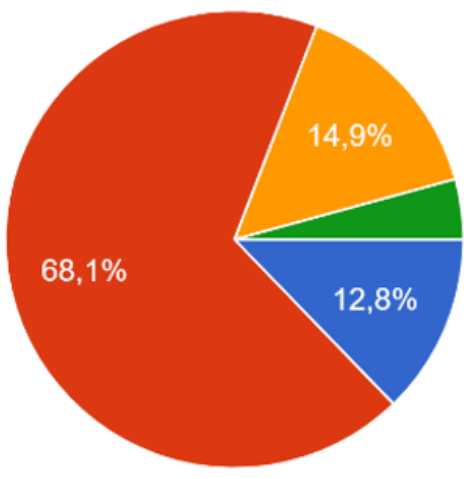

Very happy

Happy

Not really happy

Unhappy

\section{6. "Are you happy with the choice of words, pictures, videos, sounds and the web made by the lecturer?"}

Figure 8. Students feeling in Islamic materials using multimodal approach

Question number 7: How easy is it to access the material?

Figure 9 shows a total of 47 responses who gave responses. It can be detailed as the following categories: There were 33 respondents or $70.2 \%$ felt it was easy to access. A total of 5 people or $14.9 \%$ of respondents felt very easy to access. Then there were 5 respondents or $14.9 \%$ felt it was not really easy to access. From this data, the researchers concluded that most of the respondents or $85.1 \%$ felt easy to access. For more details, see the following Figure 9: 

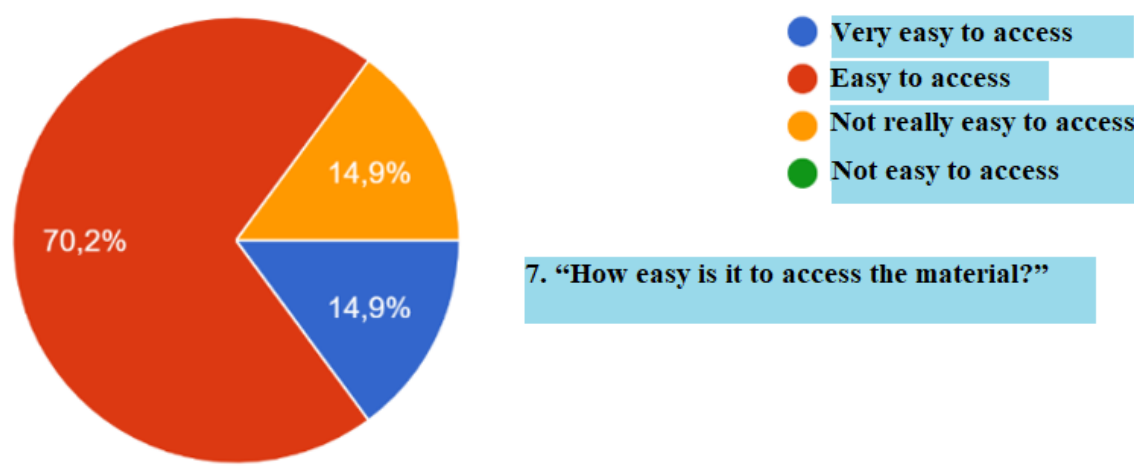

Figure 9. Students feeling in accessing materials using multimodal approach

In addition, the results of the interview question number 3 are presented below.

Question 3: What kind of English learning do you expect during a pandemic? Respondents' answers were as follows:
Participants Extracts
$R 7 \quad$ Improve language skills in learning media using telegram
R16 related to Islam and hopefully it will be more effective in the future
R23 Judging from the current condition I can only hope for learning via zoom or google meet. I hope there will be direct interaction between lecturers and students both in Google meet/zoom media in this pandemic era, even if only once or several times, so that it is hoped that learning can take place between lecturers and students getting to know each other
R31 By using zoom or similar applications, and interacting with lecturers and friends in English
R44 Face to face via zoom and better for more interaction between lecturers and students

\section{Discussion}

Dealing with learning English using Islamic materials, the data were gained from the questionnaire items number 1, 2, 8 and 9. Based on the findings from the question no.1, it can be stated that the majority of respondents $(89.4 \%)$ were interested in using Islamic materials. The findings are consistent with prior study, which found that students were focused on learning English using Islamic resources (Djamdjuri, 2020; Gusmuliana et al., 2020; Rohmah, 2012). As well, from the question no.2, the researchers concluded that most of the respondents or $82.9 \%$ stated that Islamic materials facilitated them in improving their English language skills. As it has been proven previously that the use of Islamic materials in teaching English is effective in helping the students understand the materials (Anshari \& Widyantoro, 2020). In addition, from question no. 8 , the researchers concluded that most of the respondents or $91.5 \%$ stated that Islamic materials created using multimodal approach are fascinating. This finding proved that the learning materials through multimodal design is very interesting to the students (Eisenmann \& Summer, 2020; Sakulprasertsri, 2020; Wu, 2020). Moreover, from question no.9, the researchers concluded that most of the respondents or $95.8 \%$ stated that learning materials created using multimodal approach made students joyful and pleasure. It was had been proven by some research (Nagy, 2020; Unsworth \& Mills, 2020).

Furthermore, to support the finding from the questionnaire, the answers of the five respondents selected randomly from the data were gained through interview dealing with the use of Islamic materials in learning English are as follows: The question number 1 indicate that the 
five respondents agree with the use of Islamic material in learning English because it can add Islamic insight as well as increase English skills. This is in line with the results of previous research which states that teaching materials may have the content of Islamic values that are integrated into language teaching (Lekawael et al., 2018; Sarip et al., 2018). As well as that, textbooks or teaching materials containing cultural values may affect students' lives positively (Anshari \& Widyantoro, 2020). Moreover, the answers of the five respondents to the question number 2 indicate that they are very interested in doing multimodal-based learning through multimodal media such as the use of YouTube because it is easier to understand, add insight and video media can be viewed repeatedly. This is consistent with previous findings which stated that the use of multimodal media such as Youtube can increase students' interest in learning English (Simanjuntak et al., 2021; Wang \& Chen, 2020). In addition, Islamic movies are effective at increasing students' learning motivation (Djamdjuri \& Wulandari, 2018).

Dealing with learning English through multimodal approach, the data were gained through the questionnaire items number 3, 4, 5, 6 and 7. The question number 3 stated that a total of 28 or $59.6 \%$ of respondents expressed interest in and very interested in. This condition refers to the situation of a pandemic nowadays in which many of the students expected to have direct learning. Hence, effective media would make students easier to understand and enjoy the learning process. This is in line with the opinion which states that individuals have tried to make meaning through images, sounds, gestures, and contact from old literary traditions to modern web sites on the Internet (Liang \& Lim, 2020; Narey, 2017). Moreover, from question number 4, the researchers concluded that most of the respondents chose to use YouTube media for learning English. The use of YouTube and films/movies attracts a lot of students' interests, including in learning English. This is in line with the findings of some previous research (Djamdjuri \& Wulandari, 2018; Irawan et al., 2020; Wang \& Chen, 2020). In addition, from question number 5, the researchers inferred from this data that the majority of respondents prefer to study through Zoom, then Telegram. As it was stated by (Abu-Ayfah, 2019; Alakrash et al., 2020; Lestari \& Wardhono, 2020) that Telegram is an effective media as well as Zoom in learning English. None of the students prefer WhatsApp and LMS media in this case. From the question number 5, the researchers concluded that most of the respondents or $80.9 \%$ felt happy and the digital book attracts a lot of students' interests in feeling happy and joyful. This is in line with the view of (Djamdjuri \& Wulandari, 2018; Irawan et al., 2020; Wang \& Chen, 2020). For the question number 7, it proves that easy to access was one of the features of digital media (Handayani et al., 2020; Irawati, 2018; Tóth, 2021). Furthermore, the answers from the three respondents on the interview question number 3 show the importance of communication and interaction between lecturers and students, both when learning is carried out online and offline. Based on previous research, learning English is required to make students able to communicate politely and politely both orally and in writing for various kinds of needs (e.g., in building social ties, improving knowledge through data exchange) (Unsworth \& Mills, 2020). The values of politeness that apply in the community, civilized manners become the basis of communication that must be upheld, also include tolerant behavior, respect the interlocutor, able to work together, confident, diligent, creative, tenacious, and capable of adapting to gentle, and this will be more effective if learning can be performed offline or face to face (Pike et al., 2020; Pohan \& Malik, 2018; Sih, 2020).

\section{Conclusion}

This research is a study that aims to find out students' perspectives on learning English using online Islamic materials through a multimodal approach. From the data and analysis that have been completed from the results of the questionnaire regarding the students' interest in learning English using Islamic materials, it can be concluded that: 1) most of the respondents are interested in using Islamic materials in learning English, 2) most of the respondents state that 
Islamic materials helped them to improve their English language skills, 3) most of the respondents are interested in using online Islamic materials in learning English, 4) Most of the respondents chose to use YouTube media for learning English through a multimodal approach. The use of YouTube and films/movies gets a lot of students' interests, including in English learning. 5) The majority of respondents choose Zoom and Telegram as a medium of communication in English learning. In addition, the respondents state that the learning carried out with this multimodal approach is very interesting, very good, and can help them learn English. Respondents are motivated to learn to use a multimodal approach, especially through the use of Islamic videos with native speakers through online media originating from YouTube and multimodal Islamic digital books.

The results of interviews revealing students' perspectives are: 1) Students agree with the use of Islamic materials in learning English because it can add Islamic insight as well as increase English skills, 2) they are very interested in doing multimodal-based learning through YouTube and digital books because those are interesting, effective and sharpen creativity, 3) the responses show the importance of communication and interaction between lecturers and students, both when learning is carried out online and offline. Students want to, and while learning is doing online, it is expected that direct interaction between lecturers and students can continue to function well. Hence, the use of multimodal-based materials provides interactive opportunities between lecturers and students as the Islamic materials attract students to learn English.

Declaration of conflicting interest

The authors state that there is no conflict of interest among authors to declare concerning the publication of this paper.

Funding acknowledgement

The authors received no financial support for the research, authorship, and/or publication of this article.

\section{References}

Abu-Ayfah, Z. A. (2019). Telegram App in Learning English: EFL Students' Perceptions. English Language Teaching, 13(1), 51. https://doi.org/10.5539/elt.v13n1p51

Alakrash, H. M., Norizan, A. R., \& Bustan, E. S. (2020). the Effectiveness of Employing Telegram Application in Teaching Vocabulary: a Quasai Experimental Study. Multicultural Education, 6(1), 151-159. https://doi.org/10.5281/zenodo.3905099

Anshari, M. Z., \& Widyantoro, A. (2020). Inculcating Islamic values contented in Qs. Luqman through english speaking materials. Journal of Education and Learning (EduLearn), 14(1), 62-68. https://doi.org/10.11591/edulearn.v14i1.14285

Apriani, E., Supardan, D., Sartika, E., Suparjo, S., \& Hakim, I. N. (2019). UTILIZING ICT TO DEVELOP STUDENT'S LANGUAGE ETHIC AT ISLAMIC UNIVERSITY. POTENSIA: Jurnal Kependidikan Islam, 5(1). https://doi.org/10.24014/potensia.v5i1.6279

Assiddiq, M. A. (2019). Authentic Materials in Reading Comprehension Classroom: Its Effectiveness to Indonesian EFL Students' Achievement. International Journal for

Educational and Vocational Studies, $1(7), \quad 707-712$. https://doi.org/10.29103/ijevs.v1i7.1676

Baroya, E. H. (2018). Strategi Pembelajaran Abad 21. Jurnal Lembaga Penjaminan Mutu Pendidikan Prov. DIYogyakarta, I(01), 101-115. 
Boeriswati, E. (2013). Using Sponge Puppet Strategies to Instill Characters through Storytelling to Elementary School Students in Bekasi. 2nd International Seminat on Quality and Affordable Education, ISQAE, 410-413.

Bus, A. G., Takacs, Z. K., \& Kegel, C. A. T. (2015). Affordances and limitations of electronic storybooks for young children's emergent literacy. Developmental Review, 35, 79-97. https://doi.org/10.1016/j.dr.2014.12.004

Cahyo, S. D., Rijalul, M. U. M., Rahman, A. N., \& Pratolo, B. W. (2019). Needs analysis of Islamic-based English reading material for the Muhammadiyah junior high school. 8(2), 286-292. https://doi.org/10.11591/ijere.v8i2.18647

Chaeruman, U. A., Wibawa, B., \& Syahrial, Z. (2020). Development of an instructional system design model as a guideline for lecturers in creating a course using blended learning approach. International Journal of Interactive Mobile Technologies, 14(14), 164-181. https://doi.org/10.3991/ijim.v14i14.14411

Creswell, J. W., \& Creswell, D. J. (2018). Reserach Design - Qualitative, Quantitative, aand Mixed Methods Approach (Fifth). Sage Publication, Inc.

Darmayenti, Besral, \& Yustina, L. S. (2021). Developing efl religious characters and local wisdom based efl textbook for islamic higher education. Studies in English Language and Education, 8(1). https://doi.org/10.24815/siele.v8i1.18263

Dewanti, R., \& Iskandar, I. (2012). Rancangan Pembelajaran Berbicara Bahasa Inggris Menggunakan Pendekatan Pembelajaran Berbasis Strategi. Jurnal Pendidikan Progresif, 2(2), 1-11.

Djamdjuri, D. S. (2020). Students' Interest on the Use of Islamic Teaching Materials in English Language Teaching. ICRI 2018 - International Conference Recent Innovation, Icri 2018, 2093-2100. https://doi.org/10.5220/0009939620932100

Djamdjuri, D. S., \& Wulandari, D. (2018). Meningkatkan Motivasi Anak Terhadap Pembelajaran Bahasa Inggris Melalui Program Diskusi Film Islami. Prosiding Hasil Penelitian Dosen Universitas Ibn Khaldun Bogor, 31-38. http://pkm.uikabogor.ac.id/index.php/prosiding/index

Eisenmann, M., \& Summer, T. (2020). Multimodal Literature in ELT: Theory and Practice. CLELEjournal, 8(1), 52-73.

Fandiño, F. G. E., \& Velandia, A. J. S. (2020). How an online tutor motivates E-learning English. Heliyon, 6(8). https://doi.org/10.1016/j.heliyon.2020.e04630

Gall, M., Gall, J., \& Borg, W. (2007). Educational research: an introduction. Pearson/ Allyn \& Bacon.

Gusmuliana, P., Apriani, E., \& Karolina, A. (2020). Islamic Fefac as an Interesting Learning Media to Improve Students' English Ability and Develop Their Character Values in Man Rejang Lebong. Jurnal Inovasi Pengabdian Masyarakat Pendidikan, 1(1). https://www.researchgate.net/publication/347306485

Halimah, Sumiyadi, Mulyati, Y., \& Damaianti, V. S. (2020). Critical Literacy Approach in the Teaching of Literary Appreciation Using Indonesian Short Stories. Indonesian Journal of Applied Linguistics, 10(1), 84-94. https://doi.org/10.17509/IJAL.V10I1.24992

Handayani, S., Youlia, L., Febriani, R. B., \& Syafryadin, S. (2020). the Use of Digital Literature in Teaching Reading Narrative Text. Journal of English Teaching, Applied Linguistics and Literatures (JETALL), 3(2), 65. https://doi.org/10.20527/jetall.v3i2.8445 
Huges, C. (2003). Book Review: Disseminating Qualitative Research in Educational Settings. In Theory and Research in Education (Vol. 3, Issue 2). Open University Press. https://doi.org/10.1177/147787850500300209

Hussein, S., \& Barzani, H. (2021). The Role of Technology in ELL Classes in Turkish Republic of Northern Cyprus. International Journal of Language Education, 5(2), 30-39.

Irawan, E., Ahmadi, A., Prianggono, A., Saputro, A. D., \& Rachmandani, M. S. (2020). YouTube Channel Development on Education: Virtual Learning Solutions during the Covid-19 Pandemic Institut Agama Islam Negeri Ponorogo, Indonesia Pasca Sarjana Institut Agama Islam Negeri Ponorogo, Indonesia. International Journal of Advanced Science and Technology, 29(4), 2469-2478.

Irawati, T. (2018). Digital Storybook To Improve Writing Narrative: the Ttw Strategy Presented and Tested. Jo-ELT (Journal of English Language Teaching) Fakultas Pendidikan Bahasa \& Seni Prodi Pendidikan Bahasa Inggris IKIP, 5(1), 49. https://doi.org/10.33394/joelt.v5i1.2297

Karami, A. (2019). REVIEW PAPERS PAPERS IMPLEMENTING AUDIO-VISUAL MATERIALS ( VIDEOS ), AS AN INCIDENTAL VOCABULARY LEARNING STRATEGY , IN SECOND / FOREIGN LANGUAGE LEARNERS ' VOCABULARY DEVELOPMENT : A CURRENT REVIEW OF THE MOST. I-Manager's Journal on English Language Teaching, 9(2), 2019.

Kendiani, S. D. (2020). The Islamic Characters in Teaching English. Journal of English Education and Teaching (JEET), 4(number 3), 431-448.

Khan, R. M. I., Radzuan, N. R. M., \& Farooqi, S.-H. (2021). Learners 'Perceptions on WhatsApp Integration as a Learning Tool to Develop EFL Vocabulary for Speaking Skill. 5(2), 1-14.

Khotimah, K., \& Wahyu, A. A. A. (2020). Reading in The Digital Age: Electronic Storybook as a Teaching Tool for Beginning Readers. Advances in Social Science, Education and Humanities Research, 3rd International Conference on Education Innovation (ICEI 2019), 387(Icei), 202-205. https://doi.org/10.2991/icei-19.2019.47

Khusniyah, N. L., \& Lustyantie, N. (2017). Improving English Reading Comprehension Ability through Survey, Questions, Read, Record, Recite, Review Strategy (SQ4R). English Language Teaching, 10(12), 202. https://doi.org/10.5539/elt.v10n12p202

Lekawael, R. F. J., Emzir, -, \& Rafli, Z. (2018). The Cultural Values in Texts of English Coursebooks for Junior High School in Ambon, Moluccas-Indonesia. Advances in Language and Literary Studies, 9(2), 24. https://doi.org/10.7575/aiac.alls.v.9n.2p.24

Lestari, S., \& Wardhono, A. (2020). the Use of Telegram Apps in Basic Grammar Class. 114-130.

Liang, W. J., \& Lim, F. V. (2020). A pedagogical framework for digital multimodal composing in the English Language classroom. Innovation in Language Learning and Teaching, 0(0), 115. https://doi.org/10.1080/17501229.2020.1800709

Lustyantie, N., \& Arung, F. (2020). Pembelajaran Inovatif Bahasa dan Sastra Mengembalikan Prinsip Bahasa dan Sastra Sebagai Cara Berfikir Inovatif. Yogyakarta: Deepublish. Deepublish.

Massaro, D. W. (2012). Multimodal Learning. In Encyclopedia of the Sciences of Learning (pp. 2375-2378). Springer US. https://doi.org/10.1007/978-1-4419-1428-6_273

Mills, G. E., \& Gay, L. R. (2018). Educational Research Competencies for analysis and application. In Educational Research (Twelfth). Pearson.

Moody, A. (2010). Using electronic books in the classroom to enhance emergent literacy skills in young children. Journal of Literacy and Technology, 11(4), 22-52. 
Muhali, M. (2019). Pembelajaran Inovatif Abad Ke-21. Jurnal Penelitian Dan Pengkajian Ilmu Pendidikan: E-Saintika, 3(2), 25. https://doi.org/10.36312/e-saintika.v3i2.126

Nagy, N. (2020). Multimodal literacy development in a higher education English Studies classroom. Journal of Visual Literacy, 39(3-4), 167-184. https://doi.org/10.1080/1051144X.2020.1826218

Narey, M. J. (2017). Multimodal Perspectives of Language, Literacy, and Learning in Early Childhood. Multimodal Perspectives of Language, Literacy, and Learning in Early Childhood. https://doi.org/10.1007/978-3-319-44297-6

Pike, M. A., Hart, P., Paul, S. A. S., Lickona, T., \& Clarke, P. (2020). Character development through the curriculum: teaching and assessing the understanding and practice of virtue. Journal of Curriculum Studies, 00(00), 1-18. https://doi.org/10.1080/00220272.2020.1755996

Pohan, E., \& Malik, A. (2018). Implementing of Character Values in English Language Learning and Teaching. Science, Engineering, Education, and Development Studies (SEEDS): Conference Series, 2(1). https://doi.org/10.20961/seeds.v2i1.24080

Purnawati, \& Iskandar, I. (2019). Designing Ict Competences-Integrated Syllabuses of Grammar Courses for English Language Education Study Program. Ijlecr - International Journal of Language Education and Culture Review, 5(2), 104-115. https://doi.org/10.21009/ijlecr.052.12

Ratih, M., \& Taufina. (2019). Pengembangan Bahan Ajar Membaca Permulaan dalam Pembelajaran Tematik Dengan Model Vark (Visual, Auditory, Read/Write And Kinesthetic) Di Kelas I Sekolah Dasar. JP2SD (Jurnal Dan Pengembangan Sekolah Dasar), 7(2), 82-90.

Rehman, A., \& Perveen, A. (2021). Teachers' Perceptions about the Use of Authentic Material in Pakistani EFL Classrooms. International Journal of Language Education, 5(2), 63-73.

Rohmah, Z. (2012). Incorporating Islamic Messages in the English Teaching in the Indonesian Context. International J. Soc. Sci. \& Education, 2(2), 157-165.

Sakulprasertsri, K. (2020). Teachers' integration of multimodality into 21st Century EFL classrooms in Thailand: Practice and perception. LEARN Journal: Language Education and Acquisition Research Network, 13(2), 225-242.

Sarip, M., Rafli, Z., \& Rahmat, A. (2018). Arabic Speaking Material Design Using Content and Language Integrated Learning ( CLIL ). International Journal of Humanities and Cultural Studies, 5(1), 272-286.

Sih, A. S. (2020). The Implementation of Character Building in English Language Teaching. In IAIN Surakarta. https://online210.psych.wisc.edu/wp-content/uploads/PSY210_Unit_Materials/PSY-

210_Unit01_Materials/Frost_Blog_2020.pdf\%0Ahttps://www.economist.com/specialreport/2020/02/06/china-is-making-substantial-investment-in-ports-and-pipelinesworldwide\%0Ahttp://

Simanjuntak, U. S., Silalahi, D. E., Sihombing, P. S. R., \& Purba, L. (2021). Students' Perceptions of Using Youtube As English Online Learning Media During Covid-19 Pandemic. Journal of Languages and Language Teaching, 9(2), 150. https://doi.org/10.33394/jollt.v9i2.3567

Suprayitno, E., Rois, S., \& Arifin, A. (2019). Character value: The neglected hidden curriculum in Indonesian EFL context. Asian EFL Journal, 23(3).

Tan, L., Zammit, K., D'warte, J., \& Gearside, A. (2020). Assessing multimodal literacies in practice: a critical review of its implementations in educational settings. Language and Education, 34(2), 97-114. https://doi.org/10.1080/09500782.2019.1708926 
Tóth, A. (2021). Students ' perception regarding digital education amid the COVID-19 pandemic. $1-13$.

Umirova, D. (2020). AUTHENTICITY AND AUTHENTIC MATERIALS : HISTORY AND. 8(10), $129-133$.

Ummah, H. (2019). Islamic Character Education Model Forming Politeness in Miuhammadiyah 3 Waru Junior High School. Studia Religia : Jurnal Pemikiran Dan Pendidikan Islam, 3(1). https://doi.org/10.30651/sr.v3i1.2689

Unsworth, L., \& Mills, K. A. (2020). English language teaching of attitude and emotion in digital multimodal composition. Journal of Second Language Writing, 47(February 2019), 100712. https://doi.org/10.1016/j.jslw.2020.100712

Victor, L. F. (2016). A Systemic Functional Multimodal Discourse Analysis Approach To Pedagogic Discourse. In Zhurnal Eksperimental'noi $i$ Teoreticheskoi Fiziki. $\mathrm{http} / /$ scholar.google.com/scholar?hl=en\&btnG=Search\&q=intitle:No+Title\#0

Wang, H. chun, \& Chen, C. W. yu. (2020). Learning English from YouTubers: English L2 learners' self-regulated language learning on YouTube. Innovation in Language Learning and Teaching, 14(4), 333-346. https://doi.org/10.1080/17501229.2019.1607356

$\mathrm{Wu}$, S. (2020). Multimodal Approach to Teaching English in Higher Education. Journal of Contemporary Educational Research, 4(7), 7-10. https://doi.org/10.26689/jcer.v4i7.1374

Yi, Y., Shin, D., \& Cimasko, T. (2019). Multimodal Literacies in Teaching and Learning English In and Outside of School. The Handbook of TESOL in K-12, 163-177. https://doi.org/10.1002/9781119421702.ch11

Zubaidah, S. (2019). Keterampilan Abad Ke-21: Keterampilan Yang Diajarkan Melalui Pembelajaran. Seminar Nasional Pendidikan Dengan Tema "Isu-Isu Strategis Pembelajaran MIPA Abad 21, Desember, 1-17. 